\title{
Association of the HTRA1 gene variant with age-related macular degeneration in the Japanese population
}

\author{
Keisuke Mori · Kuniko Horie-Inoue · Masakazu Kohda • \\ Izumi Kawasaki · Peter L. Gehlbach · Takuya Awata · \\ Shin Yoneya · Yasushi Okazaki · Satoshi Inoue
}

Received: 19 February 2007/Accepted: 14 May 2007/Published online: 14 June 2007

(C) The Japan Society of Human Genetics and Springer 2007

\begin{abstract}
The purpose of this investigation was to determine whether the high-temperature requirement A-1 (HTRA1) gene polymorphism is associated with age-related macular degeneration (AMD) in native, unrelated Japanese patients. A total of 123 patients with AMD and 133 control subjects without AMD were recruited for this study. The single-nucleotide polymorphism (SNP) rs11200638 in the HTRAl gene was assessed using a TaqMan assay. The risk A allele frequencies in the AMD cases and control patients were 0.577 and 0.380 , respectively, and were associated with a significant risk of developing AMD $\left(p=7.75 \times 10^{-6}\right)$. The results were more significant in subtype analyses with wet AMD $\left(p=5.96 \times 10^{-7}\right)$. We conclude that the rs11200638 variant in the HTRAl gene is strongly associated with AMD in the Japanese population. This result supports the hypothesis that the HTRAl gene may increase
\end{abstract}

Keisuke Mori and Kuniko Horie-Inoue have contributed equally to this manuscript.

K. Mori $(\bowtie) \cdot$ K. Horie-Inoue · I. Kawasaki .

S. Yoneya

Department of Ophthalmology,

Saitama Medical University, Faculty of Medicine,

38 Morohongo, Moroyama, Iruma,

Saitama 350-0495, Japan

e-mail: keisuke@saitama-med.ac.jp

K. Horie-Inoue $\cdot$ S. Inoue

Division of Gene Regulation and Signal Transduction,

Saitama Medical University, Faculty of Medicine,

Iruma, Saitama, Japan

M. Kohda · Y. Okazaki

Division of Translational Research,

Research Center for Genomic Medicine,

Saitama Medical University, Faculty of Medicine,

Iruma, Saitama, Japan susceptibility to AMD development and can participate in a potential new molecular pathway for AMD pathogenesis by extending this association across diverse ethnicities.

Keywords High-temperature requirement A-1 (HTRA1) . Age-related macular degeneration · Single-nucleotide polymorphism $\cdot$ Japanese population $\cdot$ Smoking

\section{Introduction}

Age-related macular degeneration (AMD) is the leading cause of blindness in developed countries. There are approximately 8 million people in the United States with features of early or intermediate AMD, of whom approximately 1 million will develop advanced AMD within the next 5 years (Age-Related Eye Disease Study Research Group 2000, 2003, 2005). Currently, AMD is estimated to affect about 50 million people worldwide (Klein et al. 2004).

T. Awata

Division of Endocrinology and Diabetes,

Department of Medicine,

Saitama Medical University, Faculty of Medicine,

Iruma, Saitama, Japan

T. Awata

Division of RI Laboratory, Biomedical Research Center,

Saitama Medical University, Faculty of Medicine,

Iruma, Saitama, Japan

P. L. Gehlbach

Department of Ophthalmology,

Johns Hopkins University, School of Medicine,

Baltimore, MD, USA 
AMD is a clinically heterogeneous and genetically complex disease with multiple genetic and environmental risk factors (Age-Related Eye Disease Study Research Group 2000; Zareparsi et al. 2005). Reported risk factors include ocular pigmentation, dietary factors, positive family history for AMD, high blood pressure, smoking, and several gene mutations, such as ATP binding cassette transporter retina, apolipoprotein E, angiotensin converting enzyme, and fibulin 5 (Age-Related Eye Disease Study Research Group 2000, 2005; Klein et al. 2004; Bok 2005; Allikmets et al. 1997; Allikmets 2000; Klaver et al. 1998; Souied et al. 1998; Hamdi et al. 2002; Stone et al. 2004). Moreover, familybased genome-wide and candidate region linkage studies have successfully identified several major chromosomal regions, including 1q31 and 10q26 (Klein et al. 1998; Weeks et al. 2000; Majewski et al. 2003; Seddon et al. 2003; Kenealy et al. 2004; Abecasis et al. 2004; Fisher et al. 2005).

Recently, the complement factor $\mathrm{H}$ (CFH) gene on chromosome 1q31 has been demonstrated as the first major AMD susceptibility gene, and may associate with $30-50 \%$ of AMD cases. In the $\mathrm{CFH}$ gene, the $\mathrm{Y} 402 \mathrm{H}$ variant and other intron variants have been proposed as potentially causative factors in more than ten different Caucasian populations of European descendent (Zareparsi et al. 2005; Klein et al. 2005; Haines et al. 2005; Edwards et al. 2005; Hageman et al. 2005; Li et al. 2006; Maller et al. 2006). Several studies have reported a second major susceptibility genetic locus at chromosome 10q26 for AMD, contributing independently of CFH to disease (Jakobsdottir et al. 2005; Rivera et al. 2005; Schmidt et al. 2006). Very recently, studies of Chinese (DeWan et al. 2006) and Caucasian (Yang et al. 2006) populations have demonstrated the identification of a single-nucleotide polymorphism (SNP) rs11200638 in the promoter region of the high-temperature requirement A-1 (HTRA1) gene polymorphism at this locus.

The purpose of this study is to confirm the association between this novel SNP rs11200638 in the HTRAl gene and AMD in the Japanese population, as ethnic variation has been reported in AMD-associated $\mathrm{Y} 402 \mathrm{H}$ variant and also in other diseases (Okamoto et al. 2006; Gotoh et al. 2006; Grassi et al. 2006; Lau et al. 2006; Uka et al. 2006; Fuse et al. 2006; Chen et al. 2006; Mori et al. 2005). In addition, an important question is whether the HTRAl variant and smoking are independent risk factors, and investigating this was the second objective of the present study.

\section{Methods}

\section{Subjects}

The case-control sample was composed of 123 consecutive cases with AMD ranging in age from 51 to 87 years
[71.9 $\pm 8.7 ;$ mean \pm standard deviation $(\mathrm{SD})], 89$ men and 34 women, and 133 controls without AMD ranging in age from 51 to 88 years $(67.9 \pm 9.5$; mean \pm SD), 68 men and 65 women, recruited from outpatient visits to the Department of Ophthalmology, Saitama Medical University Hospital in the Saitama prefecture, Japan. All case-control subjects were unrelated, native Japanese Asian. The study was approved by the Ethics Committee of Saitama Medical University, and all procedures were conducted in accordance with the principles of the Declaration of Helsinki. Each individual was fully informed of the purpose of, and the procedures involved in, the study. Informed written consent was obtained for each patient.

Ophthalmic examination, definition, and subtype classification of AMD

All patients with AMD and the control subjects underwent full ophthalmologic examination, including slit lamp biomicroscopy, funduscopy, and contact lens biomicroscopic examination of the retina. All AMD patients had fluorescein and/or indocyanine green fundus angiography. Complete information regarding diet, family history, systemic conditions, and lifestyle, including smoking, were documented on each subject in a predesigned questionnaire. The visual acuity of AMD patients ranged from hand motion to 20/32. AMD subtypes were diagnosed and classified using the AREDS criteria (Age-Related Eye Disease Study Research Group 2000). The inclusion criteria were as follows: (1) age of 50 years or older, (2) diagnosis of AMD in one or both eyes, (3) no association with other retinochoroidal diseases, such as angioid streaks, high myopia (greater than 6D of myopic refractive error), central serous chorioretinopathy, and presumed ocular histoplasmosis, and (4) positive family history within parents, children, or siblings. There were 104 patients with neovascular (wet form of) AMD and 19 patients with nonneovascular (dry form of) AMD. The control subjects were confirmed not to have clinical evidence of AMD by the same complete ophthalmologic examination that was used to identify the study cohort of AMD patients.

\section{Genotyping and statistical analysis}

Genomic DNA was extracted from the peripheral blood of each individual using a DNA extraction and purification kit (Wizard Genomic DNA Purification Kit, Promega, Madison, WI, USA) according to the manufacturer's instructions. The samples were genotyped using a TaqMan genotyping assay with the ABI Prism 7000 Sequence Detection System (Applied Biosystems, Foster City, CA, USA). The data were analyzed using the Allelic Discrimination Program (Applied Biosystems). 
Table 1 Allele and genotype distribution for the single-nucleotide polymorphism (SNP) rs11200638 in the high-temperature requirement A-1 (HTRA1) gene

\begin{tabular}{lllll}
\hline & \multicolumn{2}{l}{ Cases } & Controls \\
\cline { 2 - 4 } & All AMD & Wet AMD & Dry AMD & \\
\hline$n$ & 123 & 104 & 19 & 133 \\
Allele & & & & \\
G & $104(42.3)$ & $81(38.9)$ & $23(60.5)$ & $165(62.0)$ \\
A & $142(57.7)$ & $127(61.1)$ & $15(39.5)$ & $101(38.0)$ \\
Genotype & & & & \\
GG & $26(21.1)$ & $18(17.3)$ & $8(42.1)$ & $54(40.6)$ \\
GA & $52(42.3)$ & $45(43.3)$ & $7(36.8)$ & $57(42.9)$ \\
AA & $45(36.6)$ & $41(39.4)$ & $4(21.1)$ & $22(16.5)$ \\
\hline
\end{tabular}

The data are expressed as the number of subjects (\% of the entire group)

${ }^{a}$ Age-related macular degeneration

Genotype and allele frequencies between AMD cases and controls were compared using the Chi-square test for quality of proportions. Hardy-Weinburg equilibrium tests were performed by Chi-square analysis. All analysis was performed using commercially available software (SNPAlyze ver. 6.0, Dynacom, Chiba, Japan).

\section{Results}

The distributions of rs11200638 genotype and allele frequencies are given in Table 1 . The genotype frequencies in cases and controls were in Hardy-Weinburg equilibrium $(p>0.1)$. The risk A allele frequencies in all AMD cases and control patients were 0.577 and 0.380 , respectively, and were associated with a significant risk of developing AMD $\left(\chi^{2}=20.0, p=7.75 \times 10^{-6}\right)$. The odds ratio $(\mathrm{OR})$ was $2.23(95 \%$ confidence interval (CI): 1.57-3.18). In comparison to the wild-type homozygous (GG genotype), the ORs for all AMD with the homozygous risk (AA) and heterozygous risk (GA) genotypes were 4.25 (95\% CI: 2.13-8.49) and 1.89 (95\% CI: 1.04-3.45), respectively. The results were more significant in subtype analyses with wet AMD. The allele frequency Chi-square test yielded a $p$ value of $p=5.96 \times 10^{-7}$ in comparison between wet AMD cases and control patients $\left(\chi^{2}=24.9\right)$. The OR was 2.56 (95\% CI: $\left.1.76-3.72\right)$. The ORs for wet AMD with AA and GA genotypes were 5.59 (95\% CI: 2.66-11.76) and 2.37 (95\% CI: 1.22-4.59), respectively, when compared to GG (Table 2).

HTRAl SNP rs11200638 was also found to have a significant association for AMD in both smokers (subjects who had ever smoked) and nonsmokers (subjects who had never smoked). The association was more significant in nonsmokers than in smokers $\left(p=1.7 \times 10^{-4}\right.$ and $1.9 \times 10^{-2}$, respectively) (Table 3).
Table $2 p$ values and odds ratio (OR) for the SNP rs11200638 in the HTRA1 gene

\begin{tabular}{llll}
\hline & $\chi^{2}$ & $p^{*}$ & OR $(95 \% \text { CI })^{\mathrm{a}}$ \\
\hline All AMD versus controls & & & \\
Allele frequency & 20.00 & $7.75 \times 10^{-6}$ & $2.23(1.57-3.18)$ \\
Genotype AA versus GG $^{\mathrm{b}}$ & 17.55 & $2.81 \times 10^{-5}$ & $4.25(2.13-8.49)$ \\
Genotype GA versus GG $^{\mathrm{c}}$ & 4.40 & $3.59 \times 10^{-2}$ & $1.89(1.04-3.45)$ \\
Wet AMD versus controls & & & \\
Allele frequency & 24.92 & $5.96 \times 10^{-7}$ & $2.56(1.76-3.72)$ \\
Genotype AA versus GG & 21.94 & $2.82 \times 10^{-6}$ & $5.59(2.66-11.76)$ \\
Genotype GA versus GG & 6.68 & $9.76 \times 10^{-3}$ & $2.37(1.22-4.59)$ \\
\hline${ }^{*}$ Chi-square test & & \\
a Odds ratio (95\% confidence interval) \\
b Homozygous risk (AA) versus wild-type homozygous (GG) \\
c Heterozygous risk (GA) versus wild-type homozygous (GG)
\end{tabular}

Table 3 Allele frequencies, $p$ values and ORs for the SNP rs11200638 in the HTRA1 gene in smokers and nonsmokers

\begin{tabular}{llllll}
\hline & \multicolumn{2}{l}{ Smokers } & & \multicolumn{2}{l}{ Nonsmokers } \\
& Cases & Controls & & Cases & Controls \\
\hline Allele frequency & & & & \\
$\mathrm{G}$ & 0.441 & 0.588 & & 0.385 & 0.640 \\
$\mathrm{~A}$ & 0.559 & 0.412 & & 0.615 & 0.360 \\
$p^{*}$ & $1.9 \times 10^{-2}$ & & & $1.7 \times 10^{-4}$ & \\
OR $(95 \% \mathrm{CI})^{\text {a }}$ & $1.81(1.10-2.98)$ & & $2.88(1.64-5.06)$ \\
\hline
\end{tabular}

*Chi-square test

${ }^{\text {a }}$ Odds ratio (95\% confidence interval)

\section{Discussion}

In this study, we have demonstrated that the rs 11200638 variant in the HTRAl gene is strongly associated with AMD in the Japanese population. The results were more significant in subtype analyses with wet AMD. The OR for wet AMD associated with the AA and GA genotypes were 5.59 (95\% CI: 2.66-11.76) and 2.37 (95\% CI: 1.22-4.59), respectively, when compared to the GG genotype. These results are similar to the published data for Chinese (DeWan et al. 2006) and Caucasian (Yang et al. 2006) populations. Replication in diverse ethnic groups worldwide may provide a better appreciation of the role of HTRAl in AMD pathogenesis. The results presented here support the hypothesis that the HTRAl gene associates with susceptibility to AMD development, and extends this association across diverse ethnicities. In addition, our data showed that HTRAl SNP rs11200638 was also found to have a significant association for AMD in smokers and nonsmokers, and the association was more significant in nonsmokers than in smokers. This suggests that HTRAl plays a role in 
AMD pathogenesis in both smokers and nonsmokers, and probably more considerably in nonsmokers. Further studies are needed to determine this gene-environment interaction with a larger study population.

The spectrum of clinical presentation or phenotype of Japanese AMD bears some differences compared to that observed in Caucasian AMD. There are also apparent differences in some etiologic factors compared to Western World cultures. In our consecutive case series of patients presenting in an outpatient setting, we had 104 patients with wet AMD, but only 19 patients with dry AMD. These and other epidemiological features characteristic of Asian AMD have been previously reported and include; male predominance, unilateral presentation, a comparatively low incidence of soft drusen, and a greater prevalence of wet AMD (Uyama et al. 1999, 2002; Sho et al. 2003; Bird. 2003; Chang et al. 1999).

Ethnic variation has been demonstrated in the AMDassociated $\mathrm{Y} 402 \mathrm{H}$ variant of the $\mathrm{CFH}$ gene. Grassi et al. (2006) have reported the risk $\mathrm{C}$ allele frequencies in normal control populations among different ethnicities and they are as follows: Japanese 0.07 \pm 0.04 , Hispanics $0.17 \pm 0.03$, African Americans 0.35 \pm 0.04 , Caucasians $0.34 \pm 0.03$, and Somalis $0.34 \pm 0.03$. This result is consistent with the international human haplotype map (HapMap) project database (The International HapMap Consortium 2003). Several Japanese case-control studies have not achieved significance in examining the association of the Y402H variant to AMD (Okamoto et al. 2006; Gotoh et al. 2006; Uka et al. 2006; Fuse et al. 2006). Although there remains a great deal to learn relating to $\mathrm{CFH}$ variants in the Chinese population, it appears that they more closely resemble CFH variants in a Japanese population than a Western Caucasian population (Lau et al. 2006; Chen et al. 2006). In contrast to CFH variants, our data demonstrate that the HTRAl variant in a Japanese population presents similar susceptibility to AMD development with the published findings for the Chinese and Caucasian populations. This finding is also consistent with those of another Japanese study published recently (Yoshida et al. 2007). Yang et al. (2006) have shown that this SNP in the HTRAl gene is the most likely causal variant for AMD at $10 \mathrm{q} 26$ in a Caucasian cohort. They have also found that drusen in the eyes of wet AMD patients were strongly immunolabeled with HTRAl antibody. DeWan et al. (2006) applied a whole-genome association mapping strategy to a Chinese population and have found a strong association of rs11200638 in the promoter region of the HTRAl gene and wet AMD. Importantly, this group has demonstrated that rs11200638 is functional in vitro by evaluating ARPE19 and HeLaS3 cells transfected with a relevant luciferase reporter plasmid. They hypothesized that $\mathrm{CFH}$ influences the drusen formation characteristic of dry AMD, whereas HTRAl influences choroidal neovascularization, the hallmark of wet AMD. Magnusson et al. (2006) have demonstrated that the CFH variant confers a similar risk of soft drusen and advanced forms of AMD, and has hypothesized that the $\mathrm{CFH}$ variant is a major risk factor for soft drusen formation, but that additional genetic and/or environmental factors may be required for progression to neovascular AMD. The results of our and other studies (Okamoto et al. 2006; Gotoh et al. 2006; Uka et al. 2006; Fuse et al. 2006) in the Japanese population may correlate with Japanese AMD characteristics of a comparatively low incidence of soft drusen and a greater prevalence of wet AMD, and support the hypothesis proposed by Magnusson et al. (2006), DeWan et al. (2006), and Yang et al. (2006).

In summary, this study indicates that the rs11200638 variant in the HTRAl gene is strongly associated with AMD in an ancestrally and geographically distinct population, as is represented by the Japanese population. This result supports the hypothesis that the HTRAl gene may increase susceptibility to AMD development and contribute in a potentially novel molecular pathway for AMD pathogenesis.

Acknowledgments The authors wish to thank Mrs. Hisae Iwata and Mr. Seiji Iwata for their generous gift in support of this study.

\section{References}

Abecasis GR, Yashar BM, Zhao Y, Ghiasvand NM, Zareparsi S, Branham KE, Reddick AC, Trager EH, Yoshida S, Bahling J, Filippova E, Elner S, Johnson MW, Vine AK, Sieving PA, Jacobson SG, Richards JE, Swaroop A (2004) Age-related macular degeneration: a high-resolution genome scan for susceptibility loci in a population enriched for late-stage disease. Am J Hum Genet 74:482-494

Age-Related Eye Disease Study Research Group (2000) Risk factors associated with age-related macular degeneration. A casecontrol study in the age-related eye disease study: Age-Related Eye Disease Study Report Number 3. Ophthalmology 107:2224 2232

Age-Related Eye Disease Study Research Group (2003) Potential public health impact of Age-Related Eye Disease Study results: AREDS report no. 11. Arch Ophthalmol 121:1621-1624

Age-Related Eye Disease Study Research Group (2005) Risk factors for the incidence of advanced age-related macular degeneration in the Age-Related Eye Disease Study (AREDS) AREDS report no. 19. Ophthalmology 112:533-539

Allikmets R (2000) Further evidence for an association of ABCR alleles with age-related macular degeneration. The International ABCR Screening Consortium. Am J Hum Genet 67:487-491

Allikmets R, Shroyer NF, Sigh N, Seddon JM, Lewis RA, Bernstein PS, Peiffer A, Zabriskie NA, Li Y, Hutchinson A, Dean M, Lupski JR, Leppert M (1997) Mutation of the Stargardt disease gene $(\mathrm{ABCR})$ in age-related macular degeneration. Science 277:1805-1807

Bird AC (2003) The Bowman lecture. Towards an understanding of age-related macular disease. Eye 17:457-466 
Bok D (2005) Evidence for an inflammatory process in age-related macular degeneration gains new support. Proc Natl Acad Sci USA 102:7053-7054

Chang TS, Hay D, Courtright P (1999) Age-related macular degeneration in Chinese-Canadians. Can J Ophthalmol 34:266-271

Chen LJ, Liu DT, Chan WM, Liu K, Chong KK, Lam DS, Pang CP (2006) Association of complement factor $\mathrm{H}$ polymorphisms with exudative age-related macular degeneration. Mol Vis 12:15361542

The International HapMap Consortium (2003) The International HapMap Project. Nature 426:789-796

DeWan A, Liu M, Hartman S, Zhang SS, Liu DT, Zhao C, Tam PO, Chan WM, Lam DS, Snyder M, Barnstable C, Pang CP, Hoh J (2006) HTRA1 promoter polymorphism in wet age-related macular degeneration. Science 314:989-992

Edwards AO, Ritter R 3rd, Abel KJ, Manning A, Panhuysen C, Farrer LA (2005) Complement factor $\mathrm{H}$ polymorphism and age-related macular degeneration. Science 308:421-424

Fisher SA, Abecasis GR, Yashar BM, Zareparsi S, Swaroop A, Iyengar SK, Klein BE, Klein R, Lee KE, Majewski J, Schultz DW, Klein ML, Seddon JM, Santangelo SL, Weeks DE, Conley YP, Mah TS, Schmidt S, Haines JL, Pericak-Vance MA, Gorin MB, Schultz HL, Pardi F, Lewis CM, Weber BH (2005) Metaanalysis of genome scans of age-related macular degeneration. Hum Mol Genet 14:2257-2264

Fuse N, Miyazawa A, Mengkegale M, Yoshida M, Wakusawa R, Abe T, Tamai M (2006) Polymorphisms in Complement Factor H and Hemicentin-1 genes in a Japanese population with dry-type agerelated macular degeneration. Am J Ophthalmol 142:1074-1076

Gotoh N, Yamada R, Hiratani H, Renault V, Kuoriwa S, Monet M, Toyoda S, Chida S, Mandai M, Otani A, Yoshimura N, Matsuda F (2006) No association between complement factor $\mathrm{H}$ gene polymorphism and exudative age-related macular degeneration in Japanese. Hum Genet 120:139-143

Grassi MA, Fingert JH, Scheetz TE, Roos BR, Ritch R, West SK, Kawase K, Shire AM, Mullins RF, Stone EM (2006) Ethnic variation in AMD-associated complement factor $\mathrm{H}$ polymorphism p.Tyr402His. Hum Mutat 27:921-925

Hageman GS, Anderson DH, Johnson LV, Hancox LS, Taiber AJ, Hardisty LI, Hageman JL, Stockman HA, Borchardt JD, Gehrs KM, Smith RJ, Silvestri G, Russell SR, Klaver CC, Barbazetto I, Chang S, Yannuzzi LA, Barrile GR, Merriam JC, Smith RT, Olsh AK, Bergeron J, Zernant J, Merriam JE, Gold B, Dean M, Allikmets R (2005) A common haplotype in the complement regulatory gene factor $\mathrm{H}(\mathrm{HF} 1 / \mathrm{CFH})$ predisposes individuals to age-related macular degeneration. Proc Natl Acad Sci USA 102:7227-7232

Haines JL, Hauser MA, Schmidt S, Scott WK, Olson LM, Gallins P, Spencer KL, Kwan SY, Noureddine M, Gilbert JR, SchnetzBoutaud N, Agarwal A, Postel EA, Pericak-Vance MA (2005) Complement factor $\mathrm{H}$ variant increases the risk of age-related macular degeneration. Science 308:419-421

Hamdi HK, Reznik J, Castellon R, Atilano SR, Ong JM, Udar N, Tavis JH, Aoki AM, Nesburn AB, Boyer DS, Small KW, Brown DJ, Kenney MC (2002) Alu DNA polymorphism in ACE gene is protective for age-related macular degeneration. Biochem Biophys Res Commun 295:668-672

Jakobsdottir J, Conley YP, Weeks DE, Mah TS, Ferrell RE, Gorin MB (2005) Susceptibility genes for age-related maculopathy on chromosome 10q26. Am J Hum Genet 77:389-407

Kenealy SJ, Schmidt S, Agarwal A, Postel EA, De La Paz MA, Pricak-Vance MA, Haines JL (2004) Linkage analysis for agerelated macular degeneration supports a gene on chromosome 10q26. Mol Vis 10:57-61

Klaver CC, Kliffin M, van Duijn CM, Hofman A, Cruts M, Grobbee DE, van Broeckhoven C, de Jong PT (1998) Genetic association of apolipoprotein $\mathrm{E}$ with age-related macular degeneration. Am J Hum Genet 63:200-206

Klein ML, Schultz DW, Edwards A, Matise TC, Rust K, Berselli CB, Trzupek K, Welber RG, Ott J, Wirtz MK, Acott TS (1998) Agerelated macular degeneration. Clinical features in a large family and linkage to chromosome 1q. Arch Ophthalmol 116:10821088

Klein R, Peto T, Bird AC, Vannewkirk MR (2004) The epidemiology of age-related macular degeneration. Am J Ophthlamol 137:486495

Klein RJ, Zeiss C, Chew EY, Tsai JY, Sackler RS, Haynes C, Henning AK, SanGiovanni JP, Mane SM, Mayne ST, Bracken MB, Ferris FL, Ott J, Barnstable C, Hoh J (2005) Complement factor $\mathrm{H}$ polymorphism in age-related macular degeneration. Science 308:385-389

Lau LI, Chen SJ, Cheng CY, Yen MY, Lee FL, Lin MW, Hsu WM, Wei YH (2006) Association of the Y402H polymorphism in complement factor $\mathrm{H}$ gene and neovascular age-related macular degeneration in Chinese patients. Invest Ophthalmol Vis Sci 47:3242-3246

Li M, Atmaca-Sonmez P, Othman M, Branham KEH, Khanna R, Wade MS, Li Y, Liang L, Zareparsi S, Swaroop A, Abecasis GR (2006) CFH haplotypes without the Y402H coding variant show strong association with susceptibility to age-related macular degeneration. Nat Genet 38:1049-1054

Magnusson KP, Duan S, Sigurdsson H, Petursson H, Yang Z, Zhao Y, Bernstein PS, Ge J, Jonasson F, Stefansson E, Helgadottir G, Zabriskie NA, Jonsson T, Bjomsson A, Thorlacius T, Jonsson PV, Thorleifsson G, Kong A, Stefansson H, Zhang K, Stefansson K, Gulcher JR (2006) CFH Y402H confers similar risk of soft drusen and both forms of advanced AMD. PLoS Med 3:e5

Majewski J, Schultz DW, Weleber RG, Schain MB, Edwards AO, Matise TC, Acott TS, Ott J, Klein ML (2003) Age-related macular degeneration - a genome scan in extended families. Am J Hum Genet 73:540-550

Maller J, George S, Purcell S, Fagerness J, Altshuler D, Daly MJ, Seddon JM (2006) Common variation in three genes, including a noncoding variant in $\mathrm{CFH}$, strongly influences risk of age-related macular degeneration. Nat Genet 38:1055-1059

Mori M, Yamada R, Kobayashi K, Kawaida R, Yamamoto K (2005) Ethnic differences in allele frequency of autoimmune-diseaseassociated SNPs. J Hum Genet 50:264-266

Okamoto H, Umeda S, Obazawa M, Minami M, Noda T, Mizota A, Honda M, Tanaka M, Koyama R, Takagi I, Sakamoto Y, Saito Y, Miyake Y, Iwata T (2006) Complement factor H polymorphisms in Japanese population with age-related macular degeneration. Mol Vis 12:156-158

Rivera A, Fisher SA, Fritsche LG, Keilhauer CN, Lichtner P, Meitinger T, Weber BH (2005) Hypothetical LOC387715 is a second major susceptibility gene for age-related macular degeneration, contributing independently of complement factor $\mathrm{H}$ to disease risk. Hum Mol Genet 14:3227-3236

Schmidt S, Hauser MA, Scott WK, Postel EA, Agarwal A, Gallins P, Wong F, Chen YS, Spencer K, Schnetz-Boutaud N, Hains JL, Pericak-Vance MA (2006) Cigarette smoking strongly modifies the association of LOC387715 and age-related macular degeneration. Am J Hum Genet 78:852-864

Seddon JM, Santangelo SL, Book K, Chong S, Cote J (2003) A genomewide scan for age-related macular degeneration provides evidence for linkage to several chromosomal regions. Am J Hum Genet 73:780-790

Sho K, Takahashi K, Yamada H, Wada M, Nagai Y, Otsuji T, Nishikawa M, Mitsuma Y, Yamazak Y, Matsumura M, Uyama M (2003) Polypoidal choroidal vasculopathy: incidence, demographic features, and clinical characteristics. Arch Ophthalmol 121:1392-1396 
Souied EH, Benlian P, Amouyel P, Feingold J, Lagarde J-P, Munnich A, Kaplan J, Coscas G, Soubrane G (1998) The epsilon4 allele of the apolipoprotein $\mathrm{E}$ gene as a potential protective factor for exudative age-related macular degeneration. Am J Ophthalmol 125:353-359

Stone EM, Braun TA, Russell SR, Kuehn MH, Lotery AJ, Moore PA, Eastman CG, Casavant TL, Sheffield VC (2004) Missense variations in the fibulin 5 gene and age-related macular degeneration. N Engl J Med 351:346-353

Uka J, Tamura H, Kobayashi T, Yamane K, Kawakami H, Minamoto A, Mishima HK (2006) No association of complement factor $\mathrm{H}$ gene polymorphism and age-related macular degeneration in the Japanese population. Retina 26:985-987

Uyama M, Matsubara T, Fukushima I, Matsunaga H, Iwashita K, Nagai Y, Takahashi K (1999) Idiopathic polypoidal choroidal vasculopathy in Japanese patients. Arch Ophthalmol 117:1035-1042

Uyama M, Wada M, Nagai Y, Matsubara T, Matsunaga $H$, Fukushima I, Takahashi K, Matsumura M (2002) Polypoidal choroidal vasculopathy: natural history. Am J Ophthalmol 133:639-648
Weeks DE, Conley YP, Mah TS, Paul TO, Morse L, Ngo-Chang J, Dailey JP, Ferrell RE, Gorin MB (2000) A full genome scan for age-related maculopathy. Hum Mol Genet 9:1329-1349

Yang Z, Camp NJ, Sun H, Tong Z, Gibbs D, Cameron DJ, Chen H, Zhao Y, Pearson E, Li X, Chien J, DeWan A, Harmon J, Bernstein PS, Shridhar V, Zabriskie NA, Hoh J, Howes K, Zhang K (2006) A variant of the HTRA1 gene increases susceptibility to age-related macular degeneration. Science 314:992-993

Yoshida T, DeWan A, Zhang H, Sakamoto R, Okamoto H, Minami M, Obazawa M, Mizota A, Tanaka M, Saito Y, Takagi I, Hoh J, Iwata T (2007) HTRA1 promoter polymorphism predisposes Japanese to age-related macular degeneration. Mol Vis 13:545548

Zareparsi S, Branham KEH, Li M, Shah S, Klein RJ, Ott J, Hoh J, Abecasis GR, Swaroop A (2005) Strong association of the $\mathrm{Y} 402 \mathrm{H}$ variant in complement factor $\mathrm{H}$ at 1q32 with susceptibility to age-related macular degeneration. Am J Hum Genet 77:149-153 